\title{
Between Gifts and Commodities: \\ Commercial Enterprise and the \\ Trader's Dilemma on Wallis ('Uvea)
}

\section{Paul van der Grijp}

Toa abandoned all forms of gardening, obtained a loan, and built a big shed to house six thousand infant chickens flown in from New Zealand.

The chickens grew large and lovely, and Toa's fame spread. Everyone knew he had six thousand chickens and everyone wanted to taste them. A well-bred tikong gives generously to his relatives and neighbours, especially one with thousands of earthly goods. But ... Toa aimed to become a Modern Businessman, forgetting that in Tiko if you give less you will lose more and if you give nothing you will lose all.

EPELI HAU'OFA, THE TOWER OF BABEL

\begin{abstract}
Recently, the model of the trader's dilemma was developed as an analytical perspective and applied to Southeast Asia. The present paper seeks to apply this model in Western Polynesia, where many Islanders, after earning wages in Australia, New Zealand, the United States, or New Caledonia, return to open a small shop in their home village. Usually, after one or two years of generous sharing, such enterprises have to close down. I analyze this phenomenon through case studies of successful indigenous entrepreneurs on Wallis ('Uvea), with special attention to strategies they have used to cope with this dilemma.
\end{abstract}

\section{The Paradigm of the Trader's Dilemma}

The trader's dilemma is the quandary between the moral obligation to share wealth with kinfolk and neighbors and the necessity to make a profit and accumulate capital. Western scholars have recognized this dilemma

The Contemporary Pacific, Volume I5, Number 2, Fall 2003, 277-307

(C) 2003 by University of Hawai'i Press 
since the first fieldwork in economic anthropology by Bronislaw Malinowski (1922), Raymond Firth (1929; 1939), and others. Recently, it was formulated in a theoretical way by German development sociologist HansDieter Evers in his coedited volume, The Moral Economy of Trade (Evers and Schrader 1994). Evers and the authors he assembled focused on societies in Southeast Asia such as Indonesia, Singapore, and Thailand (eg, Evers I994b, I994c; Clauss I994; Buchholt 1994; Menkhoff 1994; Auansakul 1994).

The trader's dilemma may be found within two contexts: (a) The trader buys agricultural products in his village and although he often has to sell the products outside the village at a market, where laws of supply and demand exist and the profit margins are rather limited, he finds himself morally obliged to give other villagers a good price, or even eventually to share his profit with them. (b) In his village shop the trader sells imported (often industrial) products, but because of the low standard of living of the villagers he sells them at a reduced price, sometimes even on credit. In both cases the trader is confronted with the risk of either losing his working capital-and eventually going bankrupt-or losing the respect and moral support of his neighbors and kinfolk. Actually, these traders can only accumulate the necessary capital for their enterprise by cutting or circumventing the solidarity links within their social environment.

The trader's dilemma occurs mainly in peasant villages. In urban settings it is less problematic; because people tend to have fewer close relationships, there is less group solidarity and more individual mobility. In a more developed, western-style market economy, economic relations are socially "dis-embedded" and the dilemma is more of a state affair, observable in the conflict between a so-called "rational" economy with maximum profit motive and a national government that skims off (part of) this profit and redistributes it in order to maintain its own political and social legitimacy. In such cases the trader's dilemma becomes a political one. ${ }^{1}$

A classical way out of the dilemma, according to Evers (I994a), is sociocultural differentiation of peasants and traders in ethnic groups between which there is cooperation but no sharing. The results are two separate, locally coexisting worlds or "separate moral communities." The peasants and traders who create these new moral frontiers do not feel morally obliged to participate in gift giving beyond them. Other options are to convert to a new religion, ${ }^{2}$ to become an orthodox or fundamentalist member of a denomination that already exists, or to emphasize cultural values in such a way that they become a marker of an ethnic identity- 
new or invented. Evers referred to the examples of the Protestants in the Netherlands studied by Max Weber (1930) and the Santris on Java studied by Clifford Geertz (1963). Western Polynesian examples include the Mormons in Tonga (see Gordon I988), who are expected to give Io percent of their income to the Mormon church. ${ }^{3}$ The point made by Evers about marking ethnic identity is of theoretical interest because it implies that a "reinvention of tradition" (see Hobsbawm and Ranger I983; Babadzan I999) may be economically rather than politically motivated. In many societies traders are strangers, a migrant minority against whom members of the host society actively discriminate. However, it is also possible that the trading minority itself creates cultural distance in order to find a solution for the trader's dilemma. This may result in increasing social and cultural differentiation, in the formation of what may be called a "plural society." From this perspective, the trader's dilemma may serve as a motor of sociocultural change. ${ }^{4}$

On Wallis Island, however, apart from a small number of Europeans (almost exclusively French), virtually no ethnic minorities exist, and for one and a half centuries, almost all Wallisians have belonged to the Roman Catholic variant of Christianity. Given this lack of other ethnic diversity, Futunans on the island (mostly spouses of Wallisians who marry in New Caledonia and then move together back to Wallis) are actually considered relative outsiders. However, there is not the social distance between Wallisians and Futunans (as spouses and in-laws) that might be found, for instance, between Islanders and a local Chinese retailer or trader (although as far as I know there are no Chinese businesspersons on Wallis). Futunans, then, form a special sort of ethnic minority on Wallis. Those who have not married in might not be able to maintain businesses on Wallis over the long term, but those who have, still have to face the trader's dilemma.

\section{Wallisian Society and the French Administration}

Wallis, also known by the Polynesian name 'Uvea, is an island of 79.5 square kilometers, located to the north of Fiji and west of Tonga and Sāmoa. It is surrounded by a ring of coral reef and nineteen uninhabited islets (map I). ${ }^{5}$ In I 887 , Wallis was made a French protectorate, and the following year the protectorate was extended to include Futuna, some 230 kilometers distant. In 1961 the islands became a French overseas territory (territoire d'outre-mer). These constructions imposed a new politi- 
cal link between the islands, despite the fact that they host two distinct Polynesian societies with differing cultures. At present, 9,500 people live on Wallis. ${ }^{6}$ Aside from the typically Polynesian political-juridical system of chieftaincy, Wallisians and Futunans participate in parliamentary politics; in addition, a form of French administration of justice (droit commun) parallels the Wallisian one (droit coutumier) (see Aimot 1995; TrouilhetTamole and Simete 1995). At the end of the nineteenth century, the Roman Catholic mission introduced a constitution that prohibited, among other things, the selling of land. Land tenure is still exclusively controlled by Wallisian chiefs and by kin groups defined by cognatic descent, that is, descent from a common ancestor. ${ }^{7} \mathrm{~A}$ land register is nonexistent. The

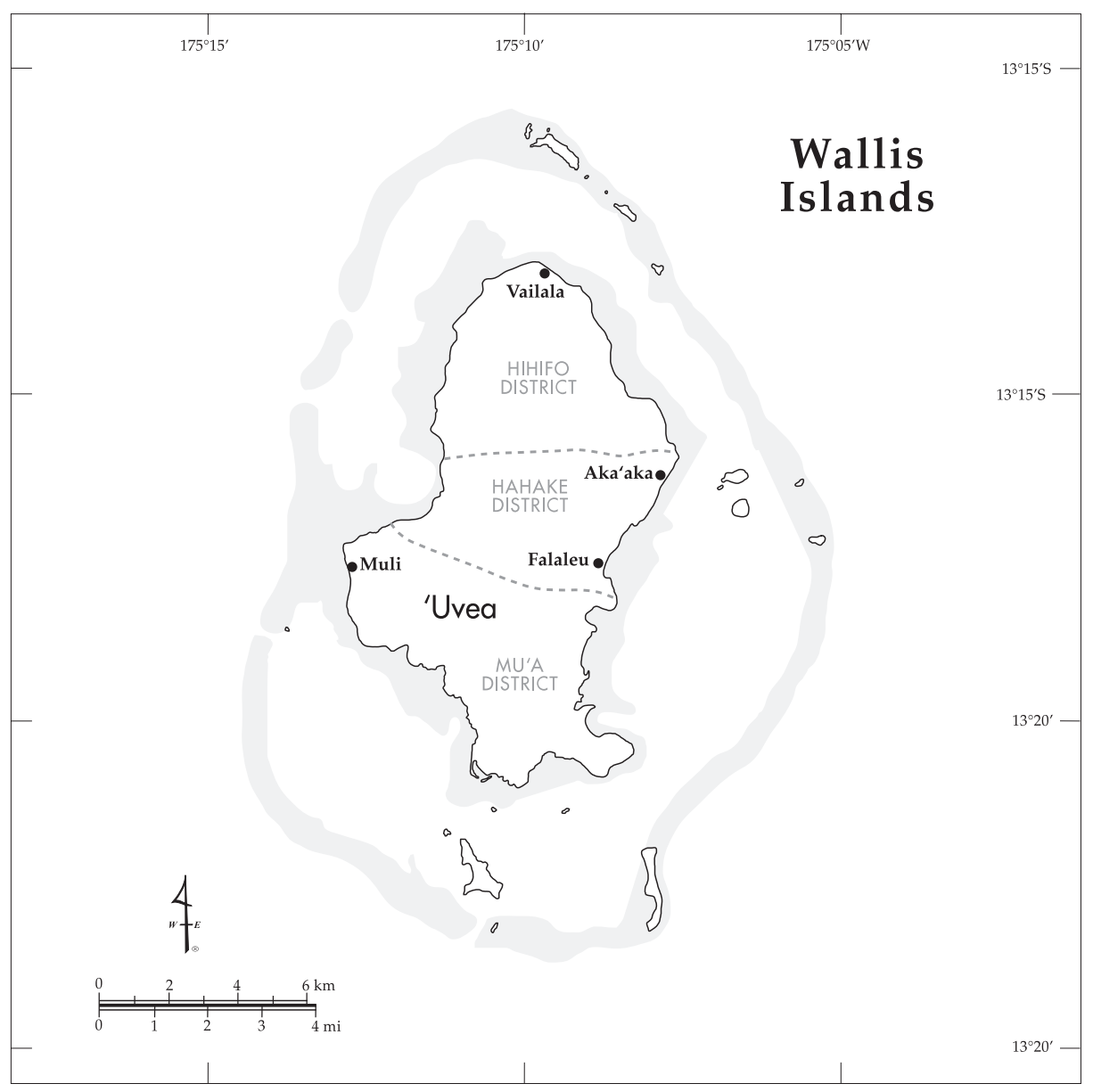

Map I 
French administration tries to maintain control over the indigenous political system through subsidies to the Wallisian chieftainship as a whole (under the label circonscription) as well as through monthly allowances to individual chiefs. ${ }^{8}$ The paramount chief (or hau) Lavelua is assisted by several other chiefs, such as the council of six high chiefs (kau 'aliki), three district chiefs (faipule), and twenty village chiefs (pule kolo). In the past, Wallis maintained an economy based on subsistence, barter, and gift exchange. At the end of the I96os, with mass emigration to New Caledonia (where many Wallisians went to work in the nickel industry), all this changed. Gradually, the island was integrated into a monetary and global economy, with the islanders increasingly becoming consumers of imported goods. Kusitino Toa, who is both a high chief ('aliki) and a trader, explained:

In the old days, the products of the island were not sold. If you needed something, you asked for it and it would be given to you freely. When I was still a child, I remember that a peasant went to see a salaried person and took with him a basket with forty kilos of yams, not to sell these, but as a gift, in the hope of receiving something in exchange, a piece of soap, for example, or a pack of sugar. This kind of barter was always to the advantage of the salaried person, because he gave whatever he pleased. If you wished to have a bunch of bananas, you cut a piece of banana leaf and pierced this with a wood splinter on the stem. Then, the owner knew that those bananas were no longer his, but were reserved for the person who had asked for them. Also, when you had been out fishing, you distributed the catch among your neighbors. This happened reciprocally. When you had caught only one fish, your children could still eat fish obtained from other fishermen. This used to be our aga' $i$ fenua [custom]. There were no losers in this system. From the time, however, that refrigerators and freezers were installed on the island, all this changed. Fishermen froze their fish instead of distributing them. All this came about because of the introduction of money. The habit of asking and giving instead of buying and selling appears to be a major obstacle to the development of a monetary economy. (Personal communication, 8 Feb 200I)

Apart from the combined economy of subsistence, barter, and gift exchange, exists a French-oriented (and protected) form of capitalism, which, however, is thwarted in its development by the unsalability of land on Wallis-private ownership of the means of production being one of the basic characteristics of capitalism. The development of capitalist entrepreneurship on Wallis has been hindered by a series of clashes over land. Recent conflicts concerned the commercial center Fripac (including the 
supermarket Super Wallis); the docks of the most important wholesaler, General Import; and the stone quarry operated by a group known as Société Wallisienne et Futunienne de Transformation et de Production (reported in the local, weekly newspaper Te Fenua Fo'ou [1996, I998, 2000 b]). Capitalism is a configuration of four elements: (I) commodity production; (2) private ownership of the means of production; (3) the use of money to make more money; and (4) wage labor (see Godelier I99I). Within this configuration, means of production and money function as capital. ${ }^{9}$ Through the exploitation of wage labor, according to the classical definition, capital is used to generate surplus value (ie, a value that exceeds the original value in the production process), and thus to accumulate capital-hence the term capitalism. These characteristics did not exist in Wallis of old, nor did they in other Polynesian societies (for Tonga, see Van der Grijp I993a, 4-6). At present, however, with increasing French influence, and a growing number of Wallisians receiving a salary from the French government (encouraging middle-class consumerism), the economic orientation on Wallis is rapidly changing. Selling land is still not allowed, but money-also in its invisible and intangible forms-is increasingly important, both in and outside the local subsistence, barter, and gift economy. The French administration has become the largest employer-and a small but growing number of Wallisians are engaged in commerce and confronted with the trader's dilemma. Because in my view the aim of anthropology should be to document how real people respond to actual circumstances, reflecting their particular wishes and desires and the logic they attribute to their own praxis (ie, their system of representations), this article focuses on biographical case studies of three entrepreneurs. ${ }^{10}$

\section{Supermarket with Sidelines}

Penisio Tialetagi was born on the Western Polynesian island of Futuna. ${ }^{11}$ After technical training in New Caledonia in several areas including coldstorage engineering, Peni went to work in telecommunications as an employee of France Cable on Wallis Island. In addition to his regular job, he had contracts with the two supermarkets and some smaller shops on the island to maintain and repair their cooling and freezing installations. He did the contract work on evenings and weekends-he was the only cold-storage engineer at that time-until he realized that his sideline was much more lucrative than his regular work for France Cable. Moreover, 
it became embarrassing when his contract clients continually called him at the state enterprise. In 1989, after nine years, he resigned from France Cable to go into business for himself full-time. Now Peni owns Wallis' third supermarket (the other two are both controlled from New Caledonia) and combines this with several other commercial activities. The question is, how was this Polynesian entrepreneur able to create such a commercial empire in the context of the local society with its dominant economy of subsistence, barter, and gift exchange?

In 1986, while still working for France Cable, Peni had opened a grocery shop in his native village, Fiua, in the Futunan district of Sigave. From the outset, in order to avoid administrative conflicts with his regular job for the French government, Peni registered the shop in the name of his younger brother, although Peni was the businessman, guiding its operation from Wallis. Staffed by his brother and two saleswomen, the small shop was supplied by ship two or three times a month. Gradually, over the years, Peni was able to expand the shop. After his voluntary resignation from France Cable, he started a nightclub on Wallis Island, and in I994 he opened a clothes shop on his wife's land ('api), halfway up a hill, about fifty meters from the main road. Since I993, Peni has practiced commercial agriculture and pig breeding. Peni himself breeds hundreds of pigs per annum; he also buys piglets in Noumea and fattens them with formulated New Zealand pig feed, supplemented with local manioc and coconuts. In I997 he started a petrol station, and in 1999 a supermarket in which he sells imported groceries as well as his own agricultural products. His most recent operation is a maintenance garage behind the supermarket and a catering service within. At present, Peni has forty-five employees, twenty of whom work full-time. In the year 2000 , his turnover was I 60 million CFP on Wallis alone (I 8 CFP equals I French franc, and IOO CFP would be about US\$I). ${ }^{12}$ Behind and beside his supermarket, he is expanding further. It is likely his supermarket will become the largest on Wallis. Peni would also like to equip a large professional fishing boat, a project of some I 20 million CFP, although finding the financing for this venture is a major problem.

Peni credited several circumstances for his success. First, he referred to a tropical cyclone and an earthquake during the first period of his commercial venture. After cyclone Radja in 1986, the French government injected almost a billion CFP in aid toward Futuna's reconstruction. After the devastating earthquake on Futuna in 1993, French aid amounted to 400 million CFP. An important part of this money, destined for the rebuild- 
ing of houses, was actually invested in the purchase of domestic appliances. If, for example, a household received $300,000 \mathrm{CFP}$, this amount was insufficient to rebuild a house (fale) but enough to buy a washing machine or refrigerator. At the time, Peni's shop on Futuna (run by his brother) was the only one selling such electrical appliances. From the outset, this coincidence gave strong impetus to Peni's commercial enterprise.

Second, Peni cited his clothes shop: "Trading clothes is less costly and the profit margin greater than, for example, selling imported groceries" (personal communication, 5 Feb 200I). The shop laid the financial groundwork for his subsequent commercial activities, such as pig breeding, the grocery trade, the garage, and the catering service. When he noticed that the bank hesitated to lend him money, he realized that he had to earn the capital himself via his commerce. Peni's explanation reflects a typical entrepreneurial belief in progress:

You cannot start all at once. When something runs well and starts to generate a profit, you may invest a part of the available money in another activity. I've always been interested in commerce. When someone has much to spend, usually this is because he has worked for it, and because he has been able to improvise things. If I hadn't believed that Wallis would develop like this within ten years, I wouldn't have had a business like this at present. I've always worked with the idea that when I earn ten francs, I have to invest five of these. When I earn two million, I will invest one million and try to keep the business running with the other million.

Third, Peni pointed to the various technical training courses he had taken as a precondition for his present activities. In I960, on his sixth birthday, he was sent from Futuna to a Roman Catholic boarding school on Wallis. Later, he continued training as an electrician in New Caledonia. Because his parents had little money, he had to earn an additional income doing small jobs in the evenings and on weekends. At the age of eighteen, he left school and found a job maintaining a fleet of trucks for a nickel mine, and at twenty-one, he signed a two-year contract with the French navy, the first year of which consisted of training as a refrigeration engineer:

I've always known that I had to be multiskilled here. At present, for example, there are many electricians on Wallis, but then they are not car mechanics as well. The precondition for running a business like mine is that I know what management is, what a workshop is, and what distribution is. The fact that I also practice commercial agriculture and breed pigs is innate. As a child, we saw every day how our parents did these things. 
Back again on his native island of Futuna, Peni discovered that jobs were distributed by local politicians. This made him decide to move to Wallis definitively. He married a Wallisian woman and went to live on her 'api. Meanwhile, he took another six-month training course in New Caledonia, to prepare for his job in telecommunications with France Cable on Wallis.

Fourth, Peni credited his large personal labor investment: "There is no big secret behind my success. I work all the time, physically as well as administratively. Both Christmas and New Year I continue working. For me these are the days when I earn more than usual." In contrast, Peni sharply criticized the apparent laziness of the younger generation:

Everybody on Wallis knows that you can earn a lot of money with fishing. But how many young people do it? They find gaue kele [traditional work] too lowly paid. Everybody wants the nice life, easy living, gaue i te pule aga [work for the French government]. Breeding pigs, however, is a daily task. You don't have any free time during the weekends. Maybe Wallisians work hard when they are abroad, but here they are lulled by the easy life. Here, they've no worries, they don't have to pay the hospital, the school, the rent, and, often, the money continues to flow. All this results in the fact that they aren't prepared to put themselves out.

There are indeed other possible points of view on this matter, such as the one formulated by Godelier when he referred to contemporary capitalist societies where "manual labour seems to be valued less and less by the workers themselves, partly because there is scarcely a trace left of that autonomy which peasants and craftsmen used to enjoy, also because manual labour is more visibly than anywhere else the nexus of relations of subordination and exploitation which many social groups, the young among others, are resisting" (I980, I74). How then could Peni, the successful Futunan businessman, escape this logic, since he followed a comparable track in the form of an overseas school career and finally arrived at something that clearly distinguished him from others? Peni's answer:

I don't have the same ideas. I come from a peasant family. At the time we said: why don't we have what others have? Through traveling and having a good look around, I saw how others do business. I thought: why them and not me? Now, I work seven days a week and eighteen hours a day. At five in the morning, I'm at work on the land, because later the sun becomes too hot. Others are not as motivated as I am.

Peni's supermarket is, indeed, the only one on the island that is open from $8 \mathrm{Am}$ to 8 PM, seven days a week, including holidays. Peni: "If you are 
prepared to work hard it is not difficult to earn money because, here, there is no income tax and the like. You can keep all profits in your pocket." This statement also indicates the fifth ingredient Peni cited for his success: the fortunate absence of wage and income taxes in the French overseas territory of Wallis and Futuna. ${ }^{13}$

In addition to the five conditions mentioned by Peni, the following circumstances also contributed. First, the recent introduction of electricity to all houses on Futuna provided the opening for the purchase of refrigerators, washing machines, and sundry electric appliances, and thus served as the driving force in Peni's early commercial activities. The introduction of universally available electricity also changed the local conception of these sorts of appliances from luxury goods to "normal" durables. Human needs, including the need for such goods, are indeed culturally and historically determined. In most cases, this type of modernization is a historically irreversible process.

A second critical circumstance was that the only bank on Wallis, the Banque de Wallis-et-Futuna (a local branch of the French multinational bank BNP-Paribas), did not wish to accord Peni a loan. Because land on Wallis is inalienable, Peni cannot obtain a mortgage on the buildings on that land. He is, of course, conscious of this and presented the situation as being somewhat to his advantage:

The bank value of my own business is nil. Because of our land tenure system, I can't take out a mortgage on it. As a Wallisian resident I took advantage of this situation, because other Wallisians can't get mortgages either. I said to myself: when I'm able to start a commercial center within ten years, other Wallisians can't copy me, because they don't have a guarantee [ie, bank mortgage value]. By then, I'll already have a concession that is worth so many millions, and I don't pay rent, I don't have to pay off my debts to the bank. Now, I've almost finished my foundations, which will be transmitted to my children. I'm at the basis of this enterprise, but after me will be my children who will have studied, who speak English and Spanish, and who will have knowledge of international law. It will be important for us to work internationally; we can earn much money abroad. For doing so, we will need a solid local base. It doesn't make sense to go out doing business abroad, if you can't do it at home. I don't have the same point of view as the French administration. When I can make a profit elsewhere, I will return here with foreign currency, and the whole economy may take advantage of that.

A third influential element can be inferred from Peni's criticism of the existing political-economic system on Wallis, the very same system that enabled him to develop his enterprise. This criticism clearly stems from an 
entrepreneurial spirit in which it is not the country that helps the economy of the entrepreneur (eg, by supplying a healthy and informed labor force), but the entrepreneur who develops the economy of the country. An entrepreneur in the commercial sector usually conceives of himself as an active agent, who uses and stimulates technological innovations and mobilizes labor and capital within a commercial project in order to make a profit. And an entrepreneur such as Peni believes that he feeds the households of his employees, despite the fact that he has received the money he gives them from the same kind of people as his employees.

A fourth circumstance of his business success is Peni's status as a Futunan married to a Wallisian wife, and thus making him a relative outsider to Wallisian society. But as mentioned earlier, this status is ambiguous and does not create sufficient social distance to completely resolve the trader's dilemma.

\section{FAmily Members Asking for Money}

Many Wallisians wishing to set up in business are constantly inhibited by aga'i fenua (custom, or in French, la coutume), which, among other things, means having to comply with frequent requests from family members for contributions (kole). As a consequence they are usually forced to renounce their business aspirations. Peni reported that he, too, is regularly confronted with this phenomenon:

When family members turn up for the first time in order to borrow money, I usually give them 5,000 or I0,000 CFP, not more. I'm not going to lend them I००,००० CFP. In this way, I limit the damage. When ordinary customers don't pay their debts, they may no longer buy anything from me. Their account is blocked automatically. At present, everything is computerized. I can't allow credit to people who don't pay. All those small shops around that went bankrupt owe this to the credit system. I'm well aware of the basic idea: family members and acquaintances come over to ask for money when they need it, but when they have money themselves they do not know you anymore. My family is here next door. I work with my children and with my wife. My family is only there when we are at home, not here in the supermarket.

In supermarkets on Wallis and Futuna people are able to buy on credit, because there is only one bank on the islands. All salaried persons, French as well as Wallisians and Futunans, are paid through this bank. At the end of the month when their salary arrives, their debt is automatically deducted from their account. Peni especially engaged an accountant in order to deal with the individual accounts of clients. According to a recent 
report published by the Service des Affaires Economiques et du Développement (SAED I998), a significant and alarming percentage of Wallisians and Futunans are deeply in debt. Peni had his own explanation for this:

A Wallisian is a proud individual. When he owns something, he feels that he has to show this to others, even if he hasn't got anything left after. The system of aga' $i$ fenua isn't bad as such, but this pride ruins people. For this very reason, most Wallisians aren't able to succeed in business. When a Wallisian earns four or five nickels, he wants to show this to everyone: look, I'm like this! Then, he buys a big car, builds a nice modern house, and fills this with expensive furniture. On Wallis, people earn I00,000 CFP and want to spend 200,000. Saving money is not their cup of tea. The pride of the people is the main problem. It's not aga' $i$ fenua that prescribes that they have to give a large feast with ten pigs at the wedding of their son or daughter, but the people do so because, motivated by their pride, they want to show off their wealth, even when they haven't got any. In other countries, the bank may overcome this problem, but not here.

At present, Peni is confronted with credit problems mainly in his pig trade. During family events (such as marriages and funerals) and large food distribution feasts (katoaga), large numbers of pigs are ceremonially gifted (see Douaire-Marsaudon I998; Favole 2000; Pechberty 1998). At such times many Wallisians immediately turn to Peni, as the largest pig breeder on the island. When someone buys a pig for I00,000 CFP from Peni and does not have the money for it straight away, the buyer may ask permission to pay off $20,000 \mathrm{CFP}$ per month. If the monthly payments are not made, Peni is obliged to go to his debtor to claim a small pig. Sometimes even that doesn't work, said Peni: "When someone doesn't pay, and you can't get a pig as compensation for the debt, then you've got to debit the amount as a loss. If you have too many such customers, you may as well close your business." Peni once more attributed excessive spending on pigs, as well as on other things, to the pride of Wallisians: "Everywhere on Wallis you can observe this pride which, so often, results in people living beyond their means. This may be expressed by the gifting of pigs, but also in excessive consumption credit in supermarkets."

\section{The Rise of a Fish Dealer}

The case study of another entrepreneur, working on a smaller scale but no less successfully, reveals another way of dealing with the trader's dilemma. In contrast to Peni, Savelina, a woman, was born on Wallis. She too spent an important part of her youth in New Caledonia, later returning to Wal- 
lis. In January I995, she opened a small fish shop on Wallis with her husband, Sosefo Tuifua. Savelina had a job in the local hospital, and Sosefo, who also had a regular job elsewhere, went out fishing every night with a few other men, two of whom were his cousins. In the community center (fale fono) they found an old, unused freezer, and the village chief agreed that Savelina and Sosefo could take it over. They had the freezer repaired by Peni, and as a salesman they engaged Savelio, Sosefo's sister's fifteenyear-old son, who had left school. After experimenting with a fish stall at an annual fair, Savelina conceived the idea of starting a more professional fish shop. She presented a proposal to the French administration for a subsidy to acquire a cold store and an ice machine, among other items. The committee to whom she made her request consisted of twelve persons, all public figures of the island: the prefet, the senator, the bank director, and so on. When she appeared in front of them, the préfet said ironically: "I did not know that a fisherwoman was hiding behind the project [Je ne savait pas qu'il y avait une pêcheresse derrière ce projet]." Savelina replied: "You are wrong, sir, I am a fisherwoman and I came here to ask pardon from all these gentlemen [Vous vous trompiez, Monsieur le Préfet, je suis une pécheresse et je suis venue ici pour me faire pardonner par tous ces messieurs]." 14 Right away, the ice was broken, but they still tried to demean her: "Where did you invent all those kilos of fish which figure in your project?" Savelina shot back: "I didn't invent them, but rely on the catch of my own fishermen, which I multiplied by five." Eventually, the project was accepted and she received a grant for starting an enterprise of I 5 percent over an amount of I I million CFP. ${ }^{15}$

When she announced the success of her subsidy request, neither her fishermen nor her husband reacted enthusiastically. She opened a bank account and deposited the subsidy in the name of Sosefo's cousin Siole. The bank director advised her against this: "Whenever he wishes, he can make off with the cash." But Savelina answered that she preferred taking the risk; for her this was a way of showing the cousin that the business was also his concern. Moreover, because she was in the French public service, she was not able to lay claim to the subsidy as a private entrepreneur.

Her husband still did not agree. She told him: "Listen, Sosefo, today you catch roo kilos, but tomorrow a restaurant keeper may buy it all, and I wouldn't have anything left. How can I run a fish shop in that case?" Savelina paid a visit to a cousin of hers in the southern district of Mu'a, a professional diver who, if he wanted, could catch more fish by himself than the four fishermen in her own group were able to. ${ }^{16}$ She also paid a visit to another cousin in $\mathrm{Mu}^{\text {'a }}$ who fished regularly with his son. In the 
northern district of Hihifo, she visited a fisherman related to her mother who used to fish with a small group, and also a father and son whom she considered the most knowledgeable of all fishermen on the island. ${ }^{17}$ Savelina had them all registered officially as being on her payroll. In this way, they can accumulate pension rights, and Savelina is able to hold on to five excellent and regular fishermen. In $\mathrm{Mu}^{\prime} \mathrm{a}$, there is an important commercial competitor but he does not have an ice machine, nor does he fillet fish. Other shops and supermarkets, however, do sell deep frozen fish. Traditionally, fish buyers wait at the waterfront for the fishermen to return with their catch. A basket of fish (ie, a woven basket of coconut palm leaves [polapola]) costs 2,000 CFP. A problem for the buyers is that they often have a long wait and do not know beforehand how much and what kind of fish they will receive for their money.

Although Savelina's fish shop officially has regular opening hours, from 6:00 AM to 7:00 PM (with a midday break from I2:30 to 3:00 PM), it is actually open day and night. Only on Sunday afternoons is the shop completely closed. Both the fishermen and the customers arrive at irregular times, and Savelina does not want to lose them. Since I995, she has an expanding clientele, including the major restaurants on the island. For a time, Sosefo's nephew continued as salesman, but when he started having personal problems, Savelina decided to remove him from the cash desk. At present, he works in the background, cleaning and maintaining the shop, and weighing and filleting fish. Savelina bought a cash register with computer program and initiated her sister-in-law, Malia, who had some previous sales experience. Later, Malia was replaced by another saleswoman. At present, two employees are working in the shop, twenty-yearold nephew Savelio and twenty-three-year-old Soana (no relation), who earn 80,000 and 75,000 CFP per month respectively. ${ }^{18}$ In I999, Savelina sold forty-four tons of fish, providing a yearly turnover of $\mathrm{I} 2$ million CFP.

The rise of this successful fish shop should be considered against the following background. As mentioned earlier, like Peni, in the course of her life Savelina made a detour via New Caledonia. At the age of five, she moved there with her parents when her father went to work in the nickel industry, and she only moved back to Wallis when she was twenty. After only a year, she was able to find work in the local hospital as a sanitary educator, and a year later, she married Sosefo, who at that time was working in a furniture factory. ${ }^{19}$ She went to live with him in his village. At night, Sosefo usually went out fishing with three men, two who were his cousins and a third who was no relation. Once, after a nighttime fishing 
expedition, one cousin (Siole) fell asleep at his day job and was fired. Sosefo and Savelina felt sorry for the man and borrowed money from the bank in order to buy, repair, and outfit a boat, which Siole and the other two men began to use for daytime fishing. Early each morning, Sosefo drove the fishermen in his car to the boat in Muli on the southwest coast of the island, supplied the petrol, and then, after working all day at his job in public works, picked up the fishermen and brought the catch to Peni's petrol station and small shop (discussed earlier). At the end of every month, the fish were paid for and Savelina distributed the money among the fishermen. This arrangement was not satisfactory, however, as Savelina noted:

Meanwhile, we had to pay petrol for the boat. Often Peni wasn't there when I came to get the check at the end of the month. Then I had to come back next morning, and sometimes again he wasn't there. At a certain moment, I was fed up with it because my time too was expensive, and I decided to sell the fish here on the spot. (Personal communication, 2I Dec 2000)

The starting point of Savelina's fish shop was the fact that her husband Sosefo used to be a prolific fisherman. Just before Savelina opened her fish shop, Sosefo had twenty fishing nets with a total length of one kilometer, and often went fishing with his cousin, though at the time, they still had no boat. At high tide, the nets were laid out in a circle within the barrier reef, and at low tide, they were pulled together and collected, a technique called fakatu' $u$ that catches mainly gray mullet, white fish ('ika hina), and a fish known in French as bec de cane. After acquiring their first boat, they laid out their nets mainly for parrotfish along the southwest coast, where fish are more plentiful than on the densely populated east coast. After Sosefo's cousin Siole left with the boat (see below), Sosefo bought another one, a bark of five meters (with a $70 \mathrm{HP}$ motor), which he can transport on a trailer behind his car. At present, Sosefo fishes with other partners, in particular when the shop needs new stock. After his job as a driver during the day, he takes a siesta and then goes out fishing. The men fish with spearguns, mainly at night. They also lay out nets for parrotfish within the lagoon, and outside the reef they troll for barracuda and tuna. Sometimes they catch sharks. Small sharks are more tender than large ones, but on Wallis there is little demand for them.

All this time, Savelina kept on with her job in the hospital, and only in I998 did she obtain ten months educational leave in order to complete her high school education via a correspondence course. Savelina and Sosefo 
have four children aged between eight and fifteen. Savelina does not want to give up her regular job and fully engage in the fish shop, in spite of the potentially higher revenue. She hopes that a close family member-at present her own children are still too young-will take over the responsibility of the fish shop so that she can engage in other activities. She also would like to expand into the sale of equipment for small fisheries.

Like Peni, Savelina is often confronted with the trader's dilemma in the form of Wallisian customers, including family members (käiga), who want to buy on credit. In such cases, she assumes a forceful attitude, and has even developed a personal strategy:

Sosefo is too kind in this regard, but here, I've got the reputation of being mean. My family members know my temperament. I also say it to my own parents: when you come over to borrow here, this means the decline of the fish shop, whereas you should help me. They understand this very well and don't oblige me to fie lelei [play the hypocrite]. Sometimes, I say loudly to my own käiga that they don't get any credit. I emphasize this in order to make it clear to my family-in-law that, if I don't give credit to my own family, I also won't give it to my family-in-law. Little by little they understand that this is part and parcel of my business. They notice that I'm not really fulupipiki [miserly] because, when there really is a problem, I do give money. I'm for real solidarity, but not for banal things.

Even within her own household, Savelina makes the distinction between the family budget and that of the fish shop. When, for example, there are dances for fundraising, she gives 5,000 CFP ("This should be enough, I don't have to show off my wealth in front of the public"). Sometimes, however, there are special things, such as in I999, when Sosefo's brother died in Noumea. Then, she took the bank notes from the cash desk straight away to pay for air tickets for Sosefo and his sister Malia, who was still working for Savelina at the time. But she also said to Malia: "I'll pay you now, but you have to pay back the money." Savelina commented:

Usually, Wallisians don't dare to say openly to a sister-in-law that she should pay something back, but I do. She returned the money to me without any problem, but if you would tell something like this to my parents-in-law, that I obliged their daughter to pay back such a loan, they would judge me very harshly in the family circle as fulupipiki or more seriously as kaikovi [avaricious]. When I've got to give, I will give, but not at the expense of my business. The husband of my sister-in-law, for example, became a pule kolo [village chief ]. When he needed ice from my machine for an event he organized in the village, I gave it to him. That was for free. 


\section{Commercial and Political Careers}

Both Peni and Savelina have in the past-and Savelina also at presentbeen salaried by the French administration (gaue $i$ te pule aga). Kusitino Toa, originating from Vailala, the most northern village on the island, does not come from such a background. For three years, from I986 till I989, Kusitino had a stall in the central market in the village of Aka'aka where, eventually he was given the job of market superintendent. At this time he became a member of the Territorial Council, a function he exercised between 1987 and 1992 (Kusitino: "Probably through my market activities I won the confidence of the people" [personal communication, 8 Feb $200 \mathrm{I}])$. Later on, he created a fishing cooperative, and for a year, he ran a construction company with Gaston Lutui, a political contact:

We had to find something else to earn money, and then we started this company. We built modern, concrete houses and even constructed a school on Futuna-we had, of course, excellent contacts with the French administration. When Gaston obtained his new political job as socioeconomic adviser, he let me down and the company broke up. In this country, the salaried person is always the winner.

Together with Mika Hoatau, another political contact, Kusitino had a company buying breadfruit on Wallis and exporting them to New Caledonia every week during the breadfruit season. ${ }^{20}$ It was good business, but it meant competition for the local producers in New Caledonia, and after two years, the Territorial Council of New Caledonia decided to stop allowing the importation of Wallisian breadfruit (Kusitino: "Evidently, this was a political decision against Wallisians"). Five years ago, Kusitino started his own shop, which was still operating in 200I. Nowadays, he runs it on his own, without an associate. He has one saleswoman on the payroll. Apart from imported food, he sells mainly local products. Since 1994, he has also been active in the chieftain circuit, initially for more than five years as village head (pule kolo) of Vailala, with the title Utumaka, and since November 2000 as high chief ('aliki) of the sea, with the title Uluimonua (see Te Fenua Fo'ou $2000 \mathrm{a}$ and 2000c).

Kusitino's political and commercial career-he has proven to be an excellent organizer-should be understood in the following context. As a young man he was a community head (lagiaki) and co-organized villagelevel public works such as the hardening of village roads with coral stone. At the time, roads were still made by hand, without the use of large 
machinery. He also used ovens to produce lime for the graves in the cemetery and for the chapel. Together with the other villagers he built a primary school in the form of a traditional house (fale). Besides such activities he participated in the construction of a community center (fale fono), for which at that time the village chief did not have a budget from the French authorities. The villagers themselves had to earn the money for the building material ("We went out fishing especially in order to raise funds from selling fish"). ${ }^{21}$

Remarkable in the biography of Kusitino, in contrast with the entrepreneurs in the first two case studies, is the creative combination of commercial and political activities. Peni referred to this issue when he spoke about the fact that the bank and the French administration were unwilling to accord him a loan:

It is like breeding pigs. I'm the only breeder on Wallis who never obtained money from the (French) administration, supposedly because I had sufficient financial means myself. There is, however, another reason why I don't receive financial support from the administration and the Territorial Council. Maybe they are afraid that, when I become too successful, I would become a candidate for the function of member of the Territorial Council or for senator. They are afraid of a rival who may become too powerful. People like me who are independent may become too powerful and thus too dangerous in the next twenty years. With this attitude it's difficult for them to give me money for my projects. (Personal communication, 5 Feb 200I)

In this comment, probably without being conscious of it, Peni pointed to one of the possible ways out of the trader's dilemma. As Evers and Schrader have suggested (1994), the embeddedness of economics in societies such as the Wallisian could act as a brake on personal accumulation of wealth and create a stimulus to develop other strategies in order to augment personal prestige. One such strategy is transformation of personal material wealth into symbolic capital (see Bourdieu 1984). This transformation could free the individual concerned from all suspicion of selfish greed, allowing him or her to develop a strong political, religious, or economic profile or power position. In Peni's case and within the logic of his discourse, however, he encounters difficulties created by those he sees as his adversaries in developing such a strong economic profile and the option of consequently developing a strong position of political power.

Savelina does not aspire to a role in the chieftaincy, because she has no chiefly ('aliki) blood, nor does she seek a role in politics, either at the village level-because she originates from outside the village, and as she says, 
she "will always remain a stranger,"-or in politics generally-because she is too frank when people come over to ask her for money. She refuses them straight away, and this, she explains, does not gain votes. Peni too, as a Futunan on Wallis, is a comparative outsider. Kusitino, in contrast, is fully integrated in the community where he operates his small business. Being particularly active in both traditional (chiefly) and modern (French state) politics, his energy in so doing may be interpreted in Bourdieu's terms as a strategy to transform personal material wealth into symbolic capital, and in Evers' model as a strategy to liberate himself from all suspicion of selfish greed.

\section{Land Rights and Other Sources of Conflict}

These case studies of commercial enterprises focus on the foundation of a successful shop, often combined with-or, sometimes, preceded by-other commercial activities. Shops usually stand on a plot of land. In the first section, I noted that land tenure on Wallis is controlled by principles of both chieftainship and cognatic descent. I also observed that it is forbidden to sell land, although money plays an increasingly important role in the local economy. Peni could not obtain a loan from the bank because the buildings on his (by definition unsalable) land do not represent mortgage value. The questions arise, then: How did Peni obtain the land for both his shop on Futuna and his business on Wallis? And what is the actual status of his land tenure? Peni's shop on Futuna is situated on the käiga (ie, the Futunan word for yard, or 'api in Wallisian) of his father's home in the village of Fiua in the Sigave district. This plot of land together with others should be divided between himself and his brothers and sisters through discussions in family meetings. An important argument for ceding the plot in Fiua to Peni was that, later, when his nieces and nephews have completed their studies, they would have prospective employment in Peni's enterprise.

The basis of Peni's business on Wallis is the yard ('api) of his wife. Peni explained how it came about:

After I married my wife, I lived twelve years with her father, who was the owner of the land. All that time, I spoiled the matua [old man], and indulged his material fantasies, also in the end when he had to go to hospital. His children live in Noumea. I told him that he should transfer his 'api to me, so that I could place my investments there. He agreed and also convinced his children of this. They can't retract the last will of their father. It was a gift to his daugh- 
ter, to me, and to our children. Because of this, I never had any problems. Ten years ago he died. After fifty years, only my name will be left, but my children, that is, my father-in-law's grandchildren, will be still active then. They will be - and are already at present - the owners of the land. I think that the old man thought it up this way. (Personal communication, 5 Feb 200I).

Thus, on both Futuna and Wallis, Peni is co-owner of the land, but he emphasizes that his children and the other grandchildren of his parents (and parents-in-law) will be the future owners of the various enterprises. Interesting in the above quotation is the passage about the "material fantasies" of his father-in-law when the latter was still alive. Actually, Peni had to pay for several air tickets to and from New Caledonia (for the old man as well as for the man's other children and grandchildren), a car, meals in restaurants, and other "luxury" goods and services. Peni's ambivalent feelings about this are reflected in the words "material fantasies," words he does not use when he makes an air trip or buys a new car for himself. Apparently, at this stage of his entrepreneurial career, he had to give in to the-for him-negative side of the trader's dilemma. Peni's business on Wallis only got off the ground after the death of his father-in-law, who in his last will gave the green light for the exclusive use of his land. However, it remains a fact-confirmed by the bank's stancethat, in legal terms, Peni's land tenure, along with his ownership of the buildings in which he runs his business activities, is precarious.

Like Peni and Kusitino, Savelina established her business on her spouse's land. (She resided in her husband's village after they married; Peni and Kusitino moved to their wife's land.) Together with her husband, Sosefo, Savelina built a house on the waterfront on Sosefo's father's 'api in the village of Falaleu. They spent years leveling the swampy land with stones and sand. After Sosefo became a truck driver in public works, he managed to unload a full truck of sand there several times. A cousin (on his mother's side), however, built a house on the same yard at the seaside, and even planted bananas and coconut trees all around. This situation is an ongoing source of dissatisfaction for Sosefo and Savelina, in part because the previously splendid sea view is now completely hidden. The division of the land had been decided already. For this reason they have considered moving house, but they have always postponed it because of the difficulties of relocating a concrete house and fish shop. Some years earlier, when Savelina had been negotiating the foundation of a cooperative with about a hundred fishermen from the district of Hahake (a project that did not succeed), the fishermen's idea was to build the sales out- 
let on the wharf of the Wallisian main village of Mata'utu. But Savelina did not want to guarantee her presence there: "I'm not going to stand on that wharf while my husband is waiting at home" (personal communication, 2I Dec 2000). Instead she proposed to put up the building herself, on her husband's land, saying to the fishermen: "On the very day you want to retire from the project, I'll keep the building and we can distribute the material." This was how it actually happened, though Savelina kept not only the shop building, but also the refrigerating apparatus.

Having a business situated on family land complicates understandings with relatives, especially those who may participate in the business. For example, in August 1995, Sosefo and Savelina took a long a trip to visit Sosefo's uncle in Tonga, one of Sosefo's cousins in Sāmoa, as well as family in Fiji, afterwards traveling back to Wallis via Vanuatu and New Caledonia. The three fishermen working for Savelina made caustic remarks, implying that Savelina and Sosefo had made this trip with their money. In I998, when the couple traveled to Fiji to buy a large luxury car, there were also some small confrontations with the fishermen. For example, when she told them, "Come in the morning at six for the petrol money for the boat," they would arrive when she was leaving for work or during her working hours in the hospital.

In I998, when Savelina ordered an ice machine from Australia, Sosefo's cousin Siole did not agree to be a party to the purchase. Savelina:

I gave him the choice: "If you fully participate in the fish shop, you participate also in the financing." But this, he didn't want to do. "Then, you will remain an ordinary fisherman and I'll pay you for your catch, 500 CFP per kilo. When you catch 200 kilo, I'll give you I00,000 CFP in cash. I sell the fish for 700 CFP per kilo. Those 200 extra francs are for the fish shop, to pay off the ice machine."

Initially, this cousin did not even want to look at the ice machine but, after a while, he said, "That's a nice machine." Savelina replied: "You should have listened to me before, then you would have been a co-owner now." With this ice machine she was able to sell fresh fish on a regular basis and the business started to prosper. One evening in I999, the three fishermen came to see Savelina with the question, "Do we or don't we actually participate in the fish shop? If the answer is positive, then we want to have our share, and if not, we will turn the place upside down!" Apparently, there had been a lack of clarity in their terms of association and in any case they were unhappy with their status as co-owners of the shop. Savelina 
and Sosefo had to talk to them until early morning in order to prevent them from carrying out their destructive project. After that they stopped working with Savelina, and sold their fish through Peni's supermarket. Most recently, a year after this rupture, they again began to sell their fish in Savelina's shop. Meanwhile, Siole paid off the boat and kept it.

\section{CONCLUSions}

In this article I have explored the model of the trader's dilemma by applying it to three case studies of commercial entrepreneurs on Wallis. On this Western Polynesian island with an economy still dominated by subsistence, barter, and gift exchange, entrepreneurs are, indeed, frequently visited by family members asking for monetary contributions (kole), and they must develop personal strategies to cope so as not to lose their working capital. In speaking about increasing social and cultural differentiation as a means to escape the trader's dilemma, Evers referred to the notion of a plural society (I994a). An uncritical use of this notion, however, can be misleading because it may suggest more profound ruptures between groups than actually exist; it suggests the absence of common values and relationships between groups; and finally, it suggests that other societies are homogeneous.

I conceive Wallisian society, rather, in terms of its embodying a version of Polynesian identity (see Van der Grijp 200I, 2003). Wallisian identity consists of a specific socioeconomic, political, and ideological system that, in ways similar to those in other Western Polynesian societies such as Tonga, Futuna, Sāmoa, and Rotuma, may be defined as a configuration of the following four features: (I) a paramount chieftainship and corresponding system of asymmetrical ideology based on the mana-taboo complex; (2) the dominant role of kinship in the social relations of production, distribution, and politics; $(3)$ a form of land tenure that is structured by principles of both chieftainship and cognatic descent; (4) an economy based on subsistence, barter, and gift exchange in which pigs, root crops, seafood, kava, mats, and tapa play a predominant part. Typically, these four features exist on Wallis not as an incidental co-occurrence but as a configuration. In spite of changes in the above features over the course of history, they still form the nucleus of the identity of Wallisian society. As Sahlins observed recently, "one of the Big Surprises of 'late capitalism' is that 'traditional' cultures are not inevitably incompatible with it nor vulnerable to it" (Sahlins 2000, 520). 
In an article on the rise of entrepreneurship related to the recent squash pumpkin boom in Tonga (Van der Grijp I997), I distinguished five common characteristics of Tonga's leading squash exporters: (I) superior education, (2) personal experience overseas, (3) working experience in government, (4) entrepreneurial spirit, and (5) having a large squash plantation of their own. The entrepreneurship in our Wallisian examples is not focused on the export of a cash crop, but on local commerce. Here, however, similar characteristics distinguish successful entrepreneurs: (I and 2) Peni and Savelina went to school in New Caledonia; Peni's technical training in various areas appeared to be particularly crucial for his enterprise. (3) Kusitino's training, on the other hand, was in chieftainship and in (government-related) local politics, although his wife, Fania, is a schoolteacher employed by the government. Peni, Savelina, and Savelina's husband Sosefo have all held government jobs, although Peni left his in order to concentrate on his expanding business. (4) Their entrepreneurial spirit is apparent in the various personal strategies they have used to circumvent the trader's dilemma, as detailed earlier. And (5) all three of them produce some of what they sell: Peni is a prosperous producer of pigs and cash crops; Kusitino also sells his own agricultural products; and fish dealer Savelina is married to a successful fisherman. The combination of such experiences, attitudes, and resources distinguish these Wallisian entrepreneurs from many other Wallisians, helping to explain how they have been able to escape the trader's dilemma, at least in a sufficient degree to successfully continue their business.

Three other important factors, which differ from the Tongan case, are the relative absence of a local market (Van der Grijp 2002), the complete absence (apart from some handicrafts) of the export of local products, and the general economic situation on the island. Wallis is an affluent central part of a French overseas territory with a comparatively high standard of living for the South Pacific, with considerable reliance on migration, remittances, aid, and bureaucracy (the MIRAB factors). In MIRAB economies (as coined by Bertram and Watters in the mid-I980s), entrepreneurs and traders operate in a global (capitalist) economic context where the local subsistence, barter, and gift economy may persist but not dominate. ${ }^{22} \mathrm{At}$ least two of our Wallisian examples, Peni and Savelina, developed into more western-style entrepreneurs than have other, more typical Polynesian village traders, buyers, and sellers who give credit to relatives and whose stores often fail because of this. They expect their kin network to produce and sell cash crops and other commodities (fish, handicrafts) to them in 
exchange for credit. The same kin can produce and sell to other village traders using their leverage as kin to encourage the giving of credit or outright gifts. At present, Peni is almost exclusively a seller to his kin and others, but not a buyer of their produce. Savelina now has a formal business with five specialized fishermen officially registered on her payroll. She carefully selected them as producers for her shop, and their arrangements are organized on a business model. At present, therefore, Peni and Savelina are now in a better position to limit or refuse credit to kin.

All the examples in this article demonstrate that, on Wallis, the trader's dilemma often takes the form of property conflicts, whether or not focused on land. This, indeed, is related to the particular legal status of land tenure on Wallis, which is traditional Polynesian and noncapitalist. Also significant is the continued dominance of the combined economy based on subsistence, barter, and gift exchange, which is at odds with the capitalist variant of monetary economy. Where anthropologists would rather speak about cultural characteristics (or, as I proposed, a configuration of features), sociologist Evers described the norms intrinsic to this subsistence, barter, and gift economy in ethical terms as "moral obligation," whereas he framed the norms for traders to accumulate capital as "rational necessity" (I994a). In his otherwise fruitful analytical model of the trader's dilemma, it remains unclear why the norms characteristic for one cultural system-or configuration-would be "moral" and those for another one "rational."

\section{Notes}

I The concept of "embeddedness" of the economy derives from Karl Polanyi (I957). Economic relations are "embedded" in (other) social relations. Later, Maurice Godelier elaborated this concept in his thesis that, in many societies studied by anthropologists, kinship relations may function as economic (or political, or religious) relations (1984, I996).

2 Within a South Pacific context, for example, people converted to the dissident religious movement Ma'ama Fo'ou in the Tongan village of Taoa; see Van der Grijp I993a, 25, 20I.

3 This percentage may appear high but is actually lower than members of some other religious denominations give to their respective churches. For contributions to the Free Wesleyan Church in Tonga, for example, see Van der Grijp I993a, 200-2 I0. 
4 Nowadays, in Western Polynesia we also know examples of larger entrepreneurs, such as the Tongan squash pumpkin exporters to Japan, who still deal with the same dilemma; see Van der Grijp 1997, 1999. For earlier studies of entrepreneurs in Fiji and Sāmoa, see Belshaw 1964, Tiffany 1975, and Macpherson 1988.

5 British and French sources refer to the main island and islets collectively as the Wallis Islands, after English explorer Captain Samuel Wallis, who arrived there in 1767 . When speaking in the indigenous language, the inhabitants of the main island call it by the older Polynesian name, 'Uvea; however, when speaking French, they call it Wallis and refer to themselves as Wallisiens and their language as wallisien (in English, Wallisians and Wallisian, respectively). The practice of the islands' inhabitants is followed in this article. This usage also has the advantage of avoiding confusion with another island called 'Uvea (or 'Ouvéa), in New Caledonia.

6 The census figure for Wallis in I996 was 9,528 and for Futuna, 4,638 (Insee/Itsee I996, I).

7 This is also the case on Futuna (see Panoff 1970); Tonga (Van der Grijp I993 b); Sāmoa (O’Meara 1990); and Rotuma (Howard 1964; Rensel 1994). For an early anthropological publication in English on Wallis, see Burrows 1937.

8 I must add that, for France, the political-economic interest of the tiny overseas territory of Wallis-and-Futuna is relatively small compared to the two other French territories in the Pacific, French Polynesia and New Caledonia. Apparently, however, there is some interest; see Aldrich I993; Chesneaux I99I; De Deckker and Lagayette 1987; Guillebaud 1976; Henningham 1992; Laux 2000; Rensch I983; Roux 1995 .

9 Money in this sense is not only physical but also implies credit, among other things. In capitalist societies, "the quantity of money is the result of many forces including the velocity of its circulation ... [Also] stocks and shares, mortgages, grain futures, real property [may] take on the functions of money" (Belshaw I965, 9-10).

IO Anthropological fieldwork on Wallis was conducted in I988-89 and in 2000-OI, funded by the Royal Netherlands Academy of Arts and Sciences and the (French) Centre National de la Recherche Scientifique, respectively.

I I In Wallis and Futuna, almost everybody knows Penisio Tialetagi via his abbreviated first name Peni, a custom maintained throughout this article.

I 2 In January 200I, I CFP equaled 0.00838 Euro. The CFP (cour franc pacifique) is also used in French Polynesia and New Caledonia.

I 3 In its overseas territory of Wallis and Futuna, however, the French state has created an artificial economy free of taxes on wages. The only taxes are on products imported from countries outside the European Economic Community (in this respect, the EEC also includes the French overseas territories in the Pacific).

I 4 This is a play on words in French, because pêcheur (fisherman) and pécheur (sinner) are pronounced in the same way. The feminine variants of these 
words differ, but since the term pêcheuse (fisherwoman) is not frequently used, pêcheresse (a nonexistent word) may easily be confused with the word for (female) sinner, pécheresse.

I 5 The cold store (with a capacity of eleven cubic meters) cost I, 300,000 CFP, and the ice machine 500,000 CFP. Savelina also bought four freezers of 700 liters each (ie, a capacity of almost three cubic meters).

I6 In I963, Savelina was born in the village of Loto'alahi in the Mu'a district.

I7 Savelina: "In the morning, the father goes out fishing, and at noon, the son comes over to bring the catch to my shop. In the afternoon, the father goes out fishing again, and in the evening, the son comes to bring the catch. At night, when the father is taking a rest, the son goes out fishing. Within the barrier reef, they lay out nets and dive with spear guns. Outside the reef, they fish for tuna and a kind of fish known in French as vivaneau with trailing bait" (personal communication, 2I Dec 2000).

I8 Depending on the turnover, Soana receives small bonuses, which act as a stimulus toward better sales.

I9 Apart from his sixteen months military service in the metropolis, and two holidays on nearby Pacific islands, Sosefo has always remained on Wallis.

20 Breadfruit (Artocarpus altilis) is not really cultivated but grows on its own on Wallis during seven months of the year. Moreover, it is a product that does not figure in ceremonial gift exchange.

2I The doors and windows of the community center were donated by Wallisian emigrants in New Caledonia originating from Vailala.

22 See Watters 1984; Bertram and Watters 1985, I986; Bertram I993, I999. For criticism concerning application of the MIRAB model in the French territories in the South Pacific, see Blanchet 1998; Poirine 1994, I998; for the Tongan case see James I991, I993; Perminow 1993; and Van der Grijp 1997, I999.

\section{References}

Aimot, Olivier

I995 Les instances juridictionnelles coutumières de Wallis et Futuna. In Coutume autochtone et évolution du droit dans le Pacifique Sud, edited by Paul de Deckker, I75-I89. Paris: L'Harmattan.

Aldrich, Robert

I993 France and the South Pacific since 1940. Honolulu: University of Hawai'i Press.

Auansakul, Pannee

I994 Chinese Rice Traders in Thailand. In Evers and Schrader, I48-I 55. Babadzan, Alain, editor

1999 Les politiques de la tradition: Identités culturelles et identités nationales 
dans le Pacifique. Special issue of the Journal de la Société des Océanistes, I09.

Belshaw, Cyril S

I964 Under the Ivi Tree: Society and Economic Growth in Rural Fiji. London: Routledge and Kegan Paul.

I965 Traditional Exchange and Modern Markets. Englewood Cliffs: Prentice Hall.

Bertram, Geoff

I993 Sustainability, Aid, and Material Welfare in Small South Pacific Island Economies, 1900-90. World Development 21:247-258.

I999 The mirab Model Twelve Years On. The Contemporary Pacific II:IO5-I 38

Bertram, Geoff, and Ray Watters

I985 The mirab Economy in South Pacific Microstates. Pacific Viewpoint 26:497-5 I9.

I986 The mira Process: Earlier Analyses in Context. Pacific Viewpoint 27:47-59.

Blanchet, Gilles

I998 L'aide et le défi d'un développement durable dans les Mers du Sud. In Le Pacifique: Un monde épars, edited by Alban Bensa and Jean-Claude Rivierre, I43-I77. Paris: L'Harmattan.

Bourdieu, Pierre

I984 Distinction: A Social Critique of the Judgment of Taste. Translated by Richard Nice. London: Routledge \& Kegan Paul. Original edition, Paris: Editions de Minuit, I979.

Buchholt, Helmut

I994 The "Great Transformation" in Minahasa, Indonesia. In Evers and Schrader, 95-IO3.

Burrows, Edwin G

I937 Ethnology of Uvea. Bulletin I 45. Honolulu: Bernice P Bishop Museum. Chesneaux, Jean

I99I The Function of the Pacific in the French Fifth Republic's "Grand Design.” Journal of Pacific History 26:256-272.

Clauss, Wolfgang

I994 Clove Traders and Peasants in Simeulue, Aceh. In Evers and Schrader, 88-94.

De Deckker, Paul, and Pierre Lagayette, editors

I987 Etats et pouvoirs dans les territoires français du Pacifique. Paris: L'Harmattan.

Douaire-Marsaudon, Françoise

I998 Les premiers fruits: Parenté, identité sexuelle et pouvoirs en Polynésie 
occidentale. Paris: Editions du CNRS et de la Maison des Sciences de l'Homme.

Evers, Hans-Dieter

I994a The Trader's Dilemma: A Theory of the Social Transformation of Markets and Society. In Evers and Schrader, 7-I4.

I994b Javanese Petty Trade. In Evers and Schrader, 68-75.

I994C The Emergence of Trade in a Peasant Society: Javanese Transmigrants in Kalimantan. In Evers and Schrader, 76-87.

Evers, Hans-Dieter, and Heiko Schrader, editors

1994 The Moral Economy of Trade: Ethnicity and Developing Markets. London and New York: Routledge.

Favole, Adriano

2000 La royauté oscillante: Ethnographie et histoire de la cérémonie d'investiture du Tu'i Agaifo d'Alo (Futuna). Journal de la Société des Océanistes I I I:195-2 I 8.

Firth, Raymond

I929 Primitive Economics of the New Zealand Maori. London: Routledge.

I939 Primitive Polynesian Economy. London: Routledge.

Geertz, Clifford

1963 Peddlers and Princes: Social Development and Economic Change in Two Indonesian Towns. Chicago: University of Chicago Press.

Godelier, Maurice

I980 Work and its Representations: A Research Proposal. History Workshop Journal 1980:164-I74.

I984 L'idéel et le matériel: Pensées, économies, sociétés. Paris: Fayard.

I99I Transitions et subordinations au capitalisme. Paris: Maison des Sciences de l'Homme.

I996 L'énigme du don. Paris: Fayard.

Gordon, Tamar

I988 Inventing Mormon Identity in Tonga. PhD dissertation. Berkeley: University of California.

Guillebaud, Jean-Claude

I976 Les confettis de l'empire. Paris: Le Seuil.

Hau'ofa, Epeli

I994 The Tower of Babel. In Tales of the Tikongs, I 8-26. Talanoa Series, Honolulu: University of Hawai'i Press. Original edition, Auckland: Longman Paul, I983.

Henningham, Stephen

1992 France and the South Pacific. Honolulu: University of Hawai'i Press. Hobsbawm, Eric, and Terence Ranger, editors

1983 The Invention of Tradition. Cambridge: Cambridge University Press. 
Howard, Alan

I964 Land Tenure and Social Change in Rotuma. Journal of the Polynesian Society 73:26-52.

Insee/Itsee

I996 RPWF 96. Mata'utu: Service Territorial de la Statistique, Territoire de Wallis et Futuna.

James, Kerry

I99I Migration and Remittances: A Tongan Village Perspective. Pacific Viewpoint 32:I-23.

I993 The Rhetoric and Reality of Change and Development in Small Pacific Communities. Pacific Viewpoint 34:I35-I 52.

Laux, Claire

2000 Les théocraties missionnaires en Polynésie (Tahiti, Hawaii, Cook, Tonga, Gambier, Wallis et Futuna) au XIXe siècle. Paris: L'Harmattan.

Macpherson, Cluny

I988 The Road to Power Is a Chainsaw: Villages and Innovation in Western Samoa. Pacific Studies I I (2): I-24.

Malinowski, Bronislaw

1922 Argonauts of the Western Pacific: An Account of Native Enterprise and Adventure in the Archipelagoes of Melanesian New Guinea. London: Routledge.

Menkhoff, Thomas

I994 Trade Routes, Trust and Tactics: Chinese Traders in Singapore. In Evers and Schrader, I04-I25.

O’Meara, Tim

I990 Samoan Planters: Tradition and Economic Development in Polynesia. Fort Worth: Holt, Reinhart, and Winston.

Panoff, Michel

I970 La terre et l'organisation sociale en Polynésie. Paris: Payot.

Perminow, Arne Aleksej

I993 Between the Forest and the Big Lagoon: The Microeconomy of Kotu Island in the Kingdom of Tonga. Pacific Viewpoint 34:I79-I92.

Pechberty, Dominique

I998 Le Katoaga. Journal de la Société des Océanistes 106:75-79.

Poirine, Bernard

I994 Rent, Emigration and Unemployment in Small Islands: The MIRAB Model and the French Overseas Departments and Territories. World Development 22 (I 2): I I69-I I99.

I998 Should We Hate or Love MiRAB? The Contemporary Pacific Io:65I05. 
Polanyi, Karl

1957 Aristotle Discovers the Economy. In Trade and Markets in Early Empires, edited by Karl Polanyi, Conrad M Arensberg, and Harry Pearson, 64-94. New York: Free Press.

Rensch, Karl

I983 Wallis and Futuna: Total Dependency. In Politics in Polynesia, edited by Ron Crocombe and Ahmed Ali, 2-I7. Suva: Institute of Pacific Studies, University of the South Pacific.

Rensel, Jan

1994 For Love or Money? Interhousehold Exchange and the Economy of Rotuma. PhD dissertation, University of Hawai'i.

Roux, Jean-Claude

1995 Wallis et Futuna: Espaces et temps recomposés, Chroniques d'une micro-insularité. Collection "Iles et Archipels" 2r. Bordeaux: Centre de Recherche sur les Espaces Tropicaux, Université Michel de Montaigne.

SAED, Service des affaires économiques et du développement

I998 Enquête sur l'endettement des ménages à Wallis et Futuna. Service des affaires économiques et du développement, Territoire des Iles Wallis et Futuna, République Française.

Sahlins, Marshall

2000 Culture in Practice: Selected Essays. New York: Zone.

Te Fenua Fo'ou

I996 L'économie locale à la merci du droit coutumier. Te Fenua Fo'ou zo:6.

I998 Droit du sol et droit de l'entreprise. Te Fenua Fo'ou I 24:4.

2000a Démissions coutumières en série à Hihifo. Te Fenua Fo'ou 2 I 2:5.

200ob Une carrière sans issue. Te Fenua Fo'ou 21 5:7.

2000 C Kusitino Toa nouveau ministre de la mer. Te Fenua Fo'ou 257:4-5.

Tiffany, Sharon

I975 Entrepreneurship and Political Participation in Western Samoa. Oceania 46:85-106.

Trouilhet-Tamole, Atonia, and Emeli Simete

1995 Les règles coutumières à Wallis et Futuna. In Coutume autochtone et évolution du droit dans le Pacifique Sud, edited by Paul de Deckker, I32-I39. Paris: L'Harmattan.

Van der Grijp, Paul

1993a Islanders of the South: Production, Kinship and Ideology in the Polynesian Kingdom of Tonga. Verhandelingen I 54. Leiden: KITLv Press.

I993b After the Vanilla Harvest: Stains in the Tongan Land Tenure System. Journal of the Polynesian Society 102:233-253.

1997 Leaders in Squash Export: Entrepreneurship and the Introduction of a New Cash Crop in Tonga. Pacific Studies 20 (I): 29-62. 
I999 Modernisation, mondialisation et identité polynésienne: Le modèle "Mirab" dans le Pacifique. La Pensée 3i 8:83-95.

$200 \mathrm{I}$ Configurations identitaires et contextes coloniaux: Une comparaison entre Tonga et Hawaii. Journal de la Société des Océanistes I I 3:177I92.

2002 Selling is Poverty, Buying a Shame: Representations of Work, Effective Leadership and Market Failures on Wallis. Oceania 73:17-34.

2003 Identity and Development: Tongan Culture, Agriculture, and the Perenniality of the Gift. Leiden: KITLV Press. In press.

Watters, Ray

I984 The Village Mode of Production in mirab Societies. Pacific Viewpoint Weber, Max 25:218-223.

1930 The Protestant Ethic and the Spirit of Capitalism. London: Allen and Unwin.

\section{Abstract}

Recently, the model of the trader's dilemma was developed as an analytical perspective and applied to Southeast Asia. This article seeks to apply the model in Western Polynesia, where many islanders, after earning wages in Australia, New Zealand, the United States, or New Caledonia, return to open a small shop in their home village. Usually, after one or two years of generous sharing, such enterprises have to close down. Here, I analyze this phenomenon through case studies of successful indigenous entrepreneurs on Wallis ('Uvea), with special attention to strategies they have used to cope with this dilemma.

KEYWORDS: trade, entrepreneurship, village shop, supermarket, gifts, Wallis ('Uvea), Polynesia 